\title{
Diet of a Piedmont population of Ctenomys mendocinus (Rodentia, Ctenomyidae): seasonal patterns and variations according sex and relative age
}

\author{
Silvia PUIG, María I. ROSI, Mónica I. CONA, \\ Virgilio G. ROIG and Susana A. MONGE
} Puig S., Rosi M. I., Cona M. I., Roig V. G. and Monge S. A. 1999. Diet of a Piedmont
population of Ctenomys mendocinus (Rodentia, Ctenomyidae): seasonal patterns and variations according sex and relative age. Acta Theriologica 44: 15-27.

Dietary composition was determined seasonally in males and females of Ctenomys mendocinus Philippi, 1869 from the Andean Piedmont (Mendoza, Argentina) during the reproductive and non-reproductive period. Reproductive condition and relative age of each animal was determined. Stomach contents were individually analyzed with the microhistological technique. Dietary generalism is supported by the high proportion of available genera eaten, but the intensity and continuity of use suggested specialization on grasses. Predation risk induces minimization of the exposure time out of the burrow, and could justify the specialization in grasses, considering that other rodents showed lower harvest and handling times for grasses than for shrubs. Males had a more varied diet than females in winter, and the opposite occurred in spring. Since males have been found to dig longer burrow systems than females in winter, searching for mates might cause males to intersect a higher number of food items during that season. Higher energetic and nutritional requirements associated with pregnancy and nursing may lead to the inclusion of more food items in the spring diet of females, and their higher specialization on grasses. Dietary similarities between immature and mature individuals suggested that age did not affect selection of diet items. Seasonal variation in dietary diversity suggested a foraging strategy adaptive to environmental seasonal variations and to the subterranean life style.

Unidad de Ecología Animal, Instituto Argentino de Investigaciones de Zonas Aridas (IADIZA-CONICET), CC. 507, 5500, Mendoza, Argentina, e-mail: spuig@lab.cricyt.edu.ar

Key words: fossorial rodents, foraging strategies, reproduction, Ctenomyidae

\section{Introduction}

High energetic requirements determined by subterranean life (Vleck 1979) force most fossorial mammals to adopt wide diets. Nevertheless, some species show a tendency to specialization in certain habitats or seasons (Nevo 1979). Different foraging strategies associated with different nutritional requirements according to age, sex or reproductive condition, are found in several rodents (Cockburn 1981, Gales 1982, Williams and Cameron 1986, Randolph et al. 1991). Besides, individual foraging behaviour can produce within-population differences in resources use, 
since some individuals select a variety of food items while other concentrate in a locally abundant item (Kincaid and Cameron 1982, Luo et al. 1994). According to these authors, individual specialization in different food items produces a more diverse dietary spectrum for the population.

The genus Ctenomys includes about 56 species widely distributed in South America (Reig et al. 1990). Very few studies have been conducted on Ctenomys diet composition (Madoery 1993, Comparatore et al. 1995), and none of them analyzes in detail the possibility of differential food resource use by different individuals of the same population. C. mendocinus Philippi, 1869, a territorial solitary species occurring in midwestern Argentina (Wilson and Reeder 1993), inhabits xerophytic shrublands in Mendoza Piedmont and the Andean Precordillera (Rosi et al. 1992a). In a Piedmont population the main diet component of $C$. mendocinus was grasses, followed by shrubs during winter (Madoery 1993).

Sexual differences in body size, reproductive activity and use of space were detected in the same population of $C$. mendocinus. Females developed their reproductive activity between midwinter and the end of summer, while males were active throughout the year. Individuals reached their sexual maturity in the reproductive season following their birth (Rosi et al. 1996a). Males were bigger and constructed more linear and extended burrow systems than females (Rosi et al. 1996b). These differences led us to expect different foraging strategies within the population.

In the present study the diet of a Mendoza Piedmont population of C. mendocinus, and its variations related to sex and relative age of individuals are seasonally analyzed.

\section{Material and methods}

\section{Study area}

The study was carried out in an area of old dunes located in the upper part of the Piedmont of the Andes mountain range ( $33^{\circ} 00^{\prime} \mathrm{S}, 69^{\circ} 10^{\prime} \mathrm{W}, 1330 \mathrm{~m}$ a.s.l., Mendoza, Argentina). The climate is arid to semiarid, with scarce annual precipitation averaging 100 to $300 \mathrm{~mm}$, and concentrated in summer. The area is frequently swept by Fohen type winds (Capitanelli 1972). The yearly hydric balance is negative. A shrubby stratum, with Neosparton aphyllum and Atriplex lampa, and a herbaceous stratum rich in grasses, especially Panicum urvilleanum, covers the dunes. This community has a floristic relationship with Larrea divaricata shrublands. Typical species of these sandy soils are Setaria mendocina, Gomphrena mendocina, Adesmia filipes. Plant cover reached $85.5 \%$, with $38.5 \%$ of $N$. aphyllum, 31\% of $P$. urvilleanum and 5\% of A. lampa (Méndez 1992).

\section{Field and laboratory methodology}

Four seasonal samplings were carried out in four different non adjacent dunes. Each sampling consisted in fifty dead-capture traps (Oneida Victor $\mathrm{N}^{\circ} 0$ ) active during 4 consecutive days. Eighteen animals were collected in April (autumn), 22 in August (winter) and 15 in November (spring) of 1991, and 21 in February (summer) of 1992. Sex and weight of each specimen were determined, and digestive tracts were fixed in $70 \%$ alcohol. 
Reproductive condition and relative age of each individual was determined following Rosi et al. (1992b, 1996a). Males were classified as mature or immature considering testes length, development degree of seminal vesicles, and presence/absence of spermatozoids in epididimous. All mature males were considered reproductive, since they were sexually active all throughout the year (Rosi et al. 1996a). Females were classified in three categories (immature, reproductive and non-reproductive matures) considering degree of development of nipples, and presence/absence of mature follicles, corpora lutea and embryos. Reproductive matures included pregnant, lactating and pregnant lactating females. In both sexes weight of eye lens identified individuals younger (all immature) and older (mature) than one year.

The digestive content of each animal was dried, cleared with diluted lye (aqueous sodium hypochlorite, $25 \% \mathrm{w} / \mathrm{v}$ ), and passed through a $71 \mu \mathrm{m}$ sieve. Material trapped in the sieve was analyzed using Baumgartner and Martins (1939) microhistological method, modified by Duci (1949), which allowed to identify the consumed plant genera, by means of differences in epidermal structure. Therefore, the identification was limited to aerial portions of plants, specifically epidermal fragments. Fifty fields per sampling unit were analyzed through a $400 \times$ microscope. Remains were identified to species level whenever possible. Only family level was reached in the case of Cactaceae. A reference key for all plant genera present in the study area $(n=68)$ was elaborated for the identification of digestive contents. Species identified in the diet were grouped in five categories: grasses, forbs, succulents, low shrubs (lower than $1 \mathrm{~m}$ ) and high shrubs (higher than $1 \mathrm{~m}$ ).

\section{Data analyses}

Relative frequencies of species eaten were obtained for each individual (Holechek and Gross 1982). Dietary variations among individuals were estimated by a multivariate coefficient of variation (Van Valen 1978); food items were considered separately and grouped by plant categories. Species with frequencies $>0.03$ were considered frequently used, following the reciprocal of the total number of species eaten criterium (Krebs 1989). Food-niche breadth for each individual was estimated with the Shannon-Wiener index ( $H^{\prime}$, Zar 1984).

Dietary variations among seasons were analyzed by the $H$ statistic of the Kruskall-Wallis ANOVA, followed by Tukey multiple comparisons $(q$ statistic, $p=0.05$ ). Comparisons between sexes and between age classes were carried out, using the $t$-test for number of frequently used resources, and the $U$-test of Mann-Whitney (Zar 1984) within each season. Differencies between sexes were analyzed separately for mature and immature animals.

\section{Results}

\section{Dietary composition and seasonal variations}

Within the 33 plant genera identified in digestive contents (Table 1) there were 12 genera of grasses and 12 genera of low shrubs. The specific richness was higher in autumn and winter ( 25 and 27 genera, respectively) than in spring and summer (18 and 14, respectively). Frequently used (at least in one season) genera were 8 grasses, 3 low shrubs and 2 high shrubs. Differences in the number of frequently used resources were detected among samplings $\left(H=27.16, p=5.5 \mathrm{E}^{-6}\right)$. The winter value (6.95) was significantly higher than those of spring $(5.20 ; q=1.755)$ and summer $(4.10 ; q=2.859)$. The autumn value (6.11) was significantly higher than that of summer $(q=2.016)$.

Grasses category was the most eaten throughout the year (79\%), with Poa, Panicum and Stipa as dominant (Fig. 1). Among low shrubs (18\%) only Atriplex 
Table 1. Relative frequencies of plant species in C. mendocinus diet in different seasons, in the Piedemont of Mendoza (Argentina). $n$ - number of animals analyzed in each sampling.

\begin{tabular}{|c|c|c|c|c|c|}
\hline \multicolumn{2}{|c|}{ Plant species } & \multirow{2}{*}{$\begin{array}{c}\begin{array}{c}\text { Autumn } \\
n=18\end{array} \\
0.088\end{array}$} & \multirow{2}{*}{$\begin{array}{c}\text { Winter } \\
n=22\end{array}$} & \multirow{2}{*}{$\begin{array}{l}\text { Spring } \\
n=15\end{array}$} & \multirow{2}{*}{$\begin{array}{c}\begin{array}{c}\text { Summer } \\
n=21\end{array} \\
0.047\end{array}$} \\
\hline El & Elymus erianthus & & & & \\
\hline Po & Poa lanuginosa & 0.250 & 0.230 & 0.447 & 0.348 \\
\hline $\mathrm{Dg}$ & Digitaria californica & 0.072 & 0.009 & 0.036 & 0.083 \\
\hline St & Stipa spp. & 0.061 & 0.104 & 0.123 & 0.064 \\
\hline $\mathrm{Br}$ & Bromus brevis & 0.037 & 0.043 & 0.024 & 0.018 \\
\hline Sp & Sporobolus cryptandrus & 0.054 & 0.018 & 0.013 & 0.065 \\
\hline $\operatorname{Tr}$ & Trichlorys crinita & 0.000 & 0.000 & 0.000 & 0.005 \\
\hline $\mathrm{Ar}$ & Aristida mendocina & 0.000 & 0.004 & 0.000 & 0.003 \\
\hline $\mathrm{Pp}$ & Pappophorum caespitosum & 0.002 & 0.006 & 0.000 & 0.000 \\
\hline Di & Diplachne dubia & 0.079 & 0.057 & 0.009 & 0.000 \\
\hline Se & Setaria mendocina & 0.013 & 0.008 & 0.013 & 0.028 \\
\hline \multirow[t]{2}{*}{$\mathrm{Pc}$} & Panicum urvilleanum & 0.154 & 0.044 & 0.066 & 0.317 \\
\hline & Grasses total & 0.810 & 0.596 & 0.759 & 0.978 \\
\hline $\mathrm{Pl}$ & Plantago lanceolata & 0.001 & 0.000 & 0.000 & 0.000 \\
\hline $\mathrm{Pa}$ & Parthenium hysterophorus & 0.000 & 0.001 & 0.000 & 0.000 \\
\hline \multirow[t]{2}{*}{ Go } & Gomphrena mendocina & 0.006 & 0.003 & 0.000 & 0.000 \\
\hline & Forbs total & 0.007 & 0.004 & 0.000 & 0.000 \\
\hline \multirow[t]{2}{*}{$\mathrm{Ca}$} & Cactaceae & 0.018 & 0.013 & 0.001 & 0.001 \\
\hline & Suculents total & 0.018 & 0.013 & 0.001 & 0.001 \\
\hline Нy & Hyalis argentea & 0.001 & 0.006 & 0.000 & 0.000 \\
\hline Ac & Acantholippia seriphiodes & 0.010 & 0.030 & 0.005 & 0.000 \\
\hline At & Artemisia mendozana & 0.000 & 0.009 & 0.007 & 0.000 \\
\hline $\mathrm{Ba}$ & Baccharis sp. & 0.001 & 0.000 & 0.000 & 0.000 \\
\hline $\operatorname{Pr}$ & Prosopidastrum globosum & 0.002 & 0.029 & 0.000 & 0.000 \\
\hline Cs & Cassia aphylla & 0.001 & 0.038 & 0.000 & 0.000 \\
\hline Ly & Lycium chilense & 0.018 & 0.000 & 0.003 & 0.001 \\
\hline $\mathrm{Ne}$ & Neosparton aphyllum & 0.024 & 0.012 & 0.012 & 0.000 \\
\hline $\mathrm{Bd}$ & Bredemeyera colletioides & 0.017 & 0.003 & 0.000 & 0.000 \\
\hline Ax & Atriplex lampa & 0.078 & 0.099 & 0.092 & 0.021 \\
\hline Ep & Ephedra ochreata & 0.000 & 0.000 & 0.001 & 0.000 \\
\hline \multirow[t]{2}{*}{ Sn } & Senecio subulatus & 0.001 & 0.112 & 0.067 & 0.000 \\
\hline & Low shrubs total & 0.153 & 0.338 & 0.187 & 0.022 \\
\hline Ps & Prosopis flexuosa & 0.001 & 0.005 & 0.000 & 0.002 \\
\hline $\mathrm{Bu}$ & Bulnesia retama & 0.000 & 0.006 & 0.000 & 0.000 \\
\hline $\mathrm{Cp}$ & Capparis spp. & 0.011 & 0.037 & 0.000 & 0.000 \\
\hline $\mathrm{La}$ & Larrea divaricata & 0.000 & 0.001 & 0.000 & 0.000 \\
\hline \multirow[t]{2}{*}{$\mathrm{Be}$} & Berberis grevilleana & 0.000 & 0.000 & 0.053 & 0.000 \\
\hline & High shrubs total & 0.012 & 0.049 & 0.053 & 0.002 \\
\hline
\end{tabular}




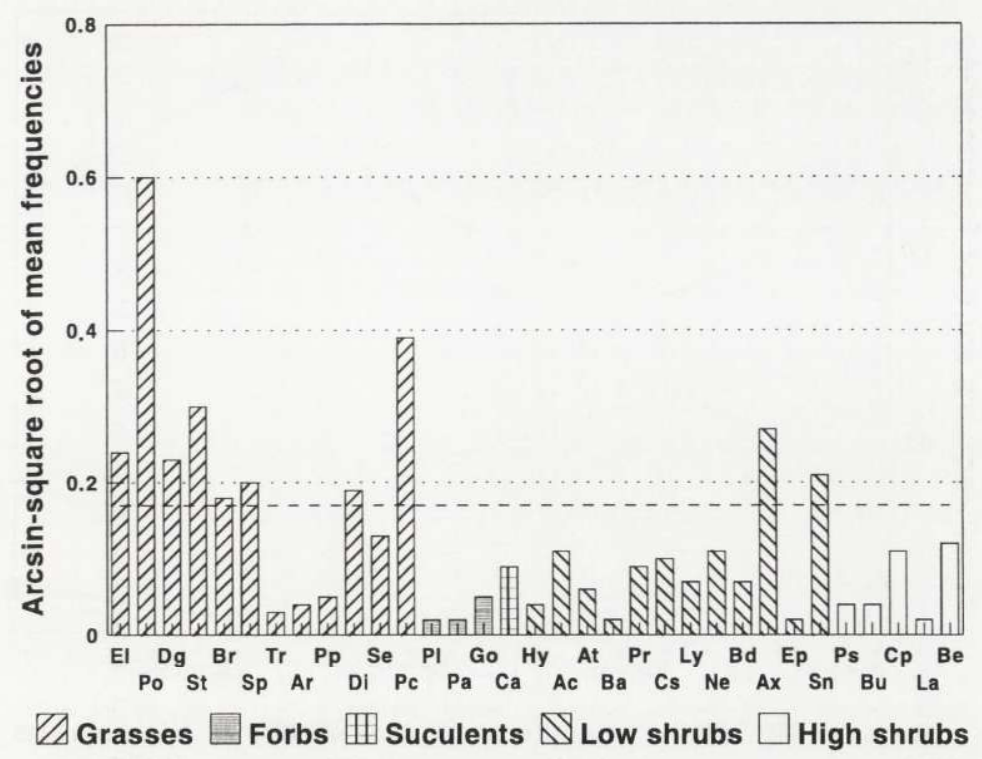

Fig. 1. Mean annual relative frequencies of plant species presented in the diet of C. mendocinus. Values were transformed using the arcsin square-root, in order to make the presence of scarce species in the diet more visible. Species identification is detailed in Table 1. The dashed line represents the chosen threshold for frequently used species.

and Senecio reached frequencies higher than $4 \%$. The other categories (forbs, succulents and low shrubs) were poorly represented in the Ctenomys diet (0.3, 0.8 and $3 \%$, respectively). Significant differences among samplings were detected for grasses $\left(H=39.76, p=1.20 \mathrm{E}^{-8}\right)$, low shrubs $\left(H=34.75, p=1.38 \mathrm{E}^{-7}\right)$ and high shrubs $(H=10.6, p=0.01)$. Use of grasses was low in winter, increased in spring and reached its highest value in summer (Fig. 2). Significant differences in the dietary proportion of grasses were registered between winter and summer, and between all the consecutive seasons (Table 2). Low shrubs proportions showed a tendency opposite to that of grasses; winter values significantly differed from those of other seasons. Variations in high shrubs dietary frequencies were similar to those of low shrubs (Fig. 2), but seasonal differences were not significant.

Grasses accounted for $67 \%$ of Ctenomys yearly diet (Table 1). Poa was the most eaten item, its highest use occuring in spring. Panicum use was high in summer, but decreased to very low frequencies in winter and spring. During these seasons the highest frequencies of Stipa were obtained. Other grasses constantly used, but at low frequencies, were Elymus, Digitaria, Bromus, Sporobolus, and Setaria. Among low shrubs, only Atriplex was used throughout the year, most intensively in winter. Another important low shrub in the winter and spring diets was Senecio. Succulents were present throughout the year, reaching their highest use in the autumn-winter period. 


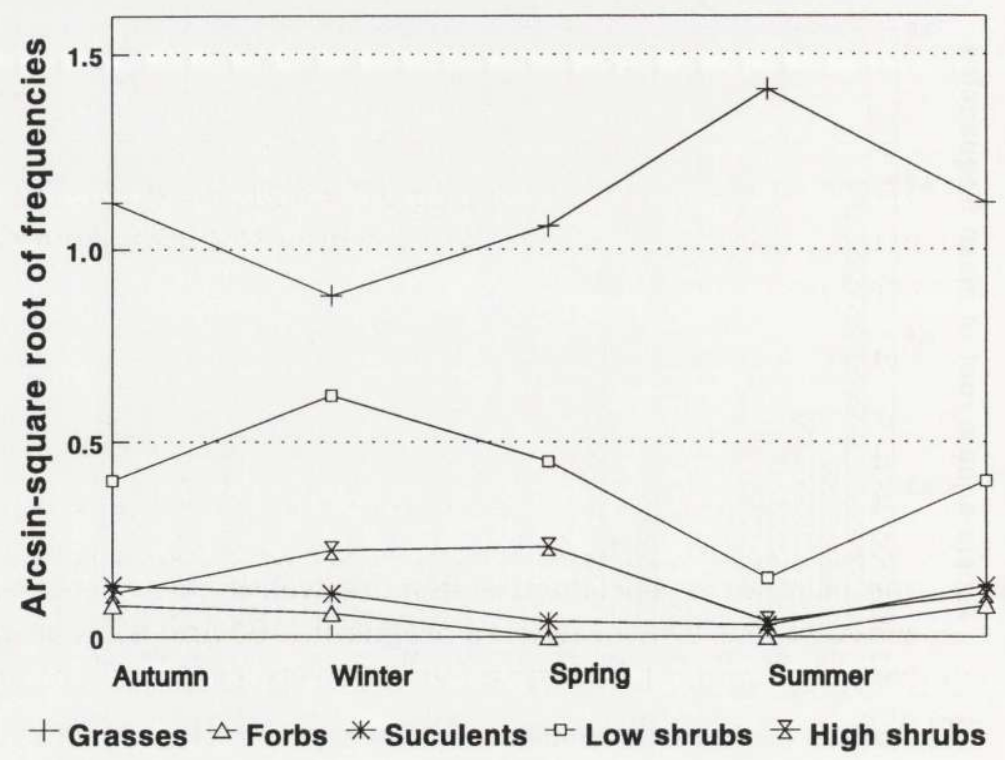

Fig. 2. Seasonal variations of relative frequencies of each plant category in $C$. mendocinus diet. Values were transformed with arcsin of square-root.

A clearly seasonal use was detected in several genera. The grass Pappophorum, the three genera of forbs, the low shrubs Hyalis, Baccharis, Prosopidastrum, Cassia and Bredemeyera, and the high shrubs Bulnesia, Capparis and Larrea were included in the autumn-winter diet. The low shrub Ephedra and the high shrub Berberis were eaten only in spring, and the grass Trichloris only in summer.

Food-niche breadth showed significant seasonal differences $(H=31.05, p=8.3$ $\left.\mathrm{E}^{-7}\right)$, with values higher in autumn and winter $\left(H^{\prime}=0.72\right.$ and 0.76 , respectively) than in spring and summer $\left(H^{\prime}=0.61\right.$ and 0.52 , respectively). Autumn niche

Table 2. Multiple comparisons among seasonal relative frequencies of grasses (G), low shrubs (Ls) and high shrubs (Hs). Values of the Tukey $q$ statistic are considered significant $\left(^{*}\right)$ when the significance level was lower than 0.05 .

\begin{tabular}{|c|c|c|c|c|c|c|c|c|c|}
\hline \multirow{2}{*}{ Season } & \multicolumn{3}{|c|}{ Winter } & \multicolumn{3}{|c|}{ Spring } & \multicolumn{3}{|c|}{ Summer } \\
\hline & G & Ls & $\mathrm{Hs}$ & G & Ls & $\mathrm{Hs}$ & G & Ls & $\mathrm{Hs}$ \\
\hline Autumn & $\begin{array}{c}0.213 \\
*\end{array}$ & $\begin{array}{c}-0.185 \\
*\end{array}$ & -0.036 & 0.051 & -0.033 & -0.041 & $\begin{array}{c}-0.165 \\
*\end{array}$ & 0.131 & 0.010 \\
\hline Winter & & & & $\begin{array}{c}-0.161 \\
*\end{array}$ & $\begin{array}{c}0.151 \\
*\end{array}$ & -0.005 & $\begin{array}{c}-0.378 \\
*\end{array}$ & $\begin{array}{c}0.316 \\
*\end{array}$ & 0.046 \\
\hline Spring & & & & & & & $\begin{array}{c}-0.216 \\
*\end{array}$ & $\begin{array}{c}0.165 \\
*\end{array}$ & 0.051 \\
\hline
\end{tabular}


breadth differed significantly from that of spring $(q=0.105)$ and summer ( $q=0.098$ ), and the two latter differed from that of winter $(q=0.101$ and $q=0.093$, respectively). Diet diversity considering plant categories changed seasonally $\left(H=35.52, p=9.4 \mathrm{E}^{-8}\right)$; summer diversity $\left(H^{\prime}=0.04\right)$ was significantly lower than in winter $\left(H^{\prime}=0.30, q=0.095\right)$ and spring $\left(H^{\prime}=0.21, q=0.10\right)$. The variation coefficient among individuals ranged from $49 \%$ in winter to $4.9 \%$ in summer; spring showed an intermediate value $(38 \%)$.

\section{Dietary variation between sexes and among age classes}

Dietary comparisons between sexes were made seasonally. Comparisons among animals older and younger than one year old could only be obtained in summer and autumn, due to seasonal changes in population structure. Mature males were captured in all seasons, with the highest percentages in winter $(85 \%)$ and spring $(100 \%)$. Proportion of mature reproductive females was high in both seasons (89 and $100 \%$, respectively), most of these were pregnant (100 and $67 \%$, respectively). Lactating females and pregnant lactating females were captured only in spring. The proportion of mature females was very low in summer (14\%); all of them were
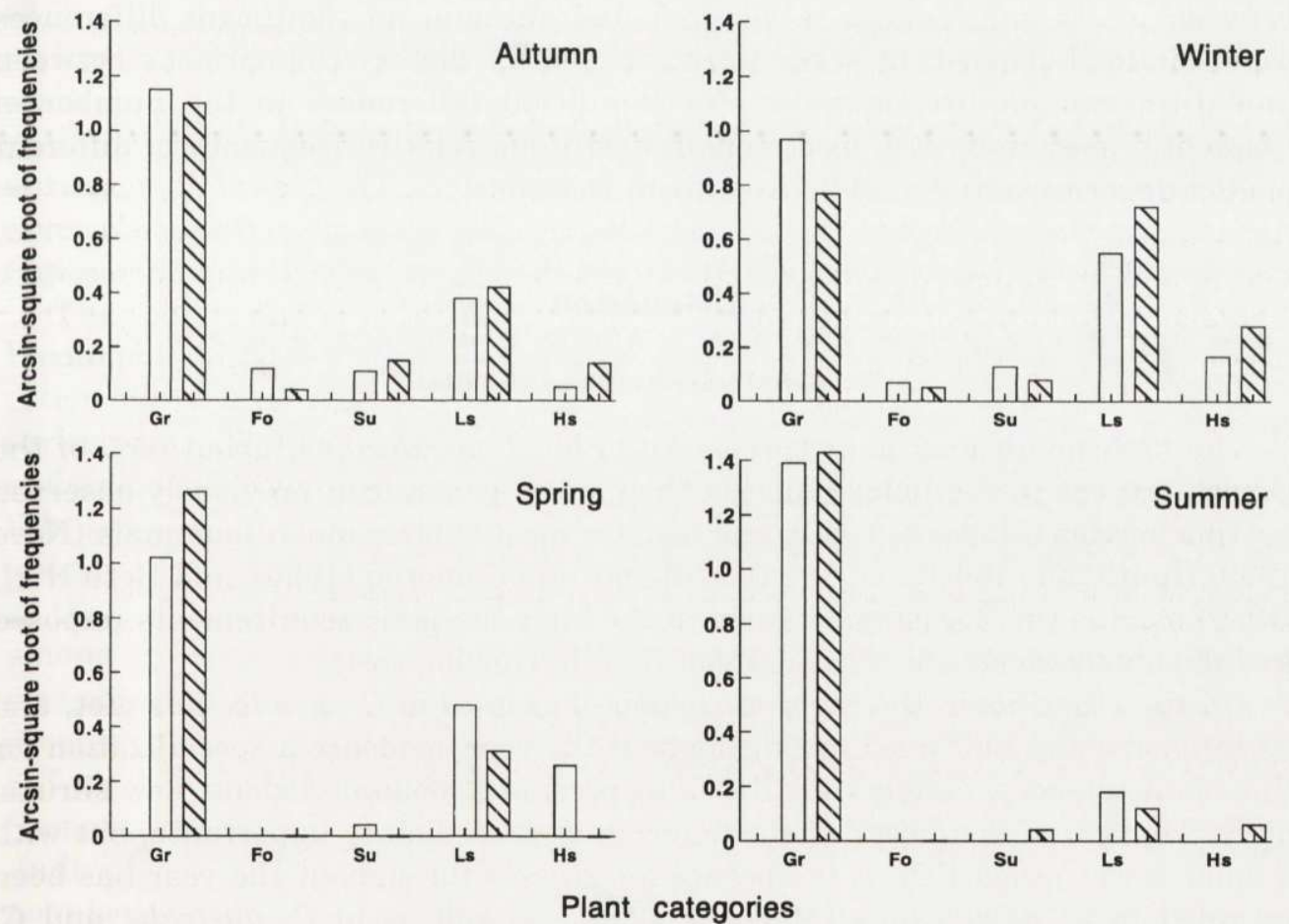

Fig. 3. Relative frequencies of plant categories ( $\mathrm{Gr}$ - grasses, Fo - forbs, Su - succulents, Ls - low shrubs, Hs - high shrubs) in the diet of males (open) and females (hatched) in different seasons. Values were transformed with arcsin of square-root. 
pregnant while no reproductive female was captured in autumn. Immature animals reached proportions similar to those of mature ones in summer $(43 \%)$ and autumn (50\%). This percentage decreased in winter (14\%) due to sexual maturity, and no immature animal was captured in spring.

Males frequently used a significantly higher number of species than females in winter (7.6 and 6.0, respectively; $t=2.17, p=0.04$ ), but a significantly lower number in spring ( 4.8 and 7.0, respectively; $t=-2.79, p=0.02$ ). Dietary proportions of different plant categories were similar in both sexes (Fig. 3) except for spring $(U=33 ; \mathrm{df}=12,3, p<0.05)$, when females concentrated on grasses $(91 \%)$, while high shrubs were eaten only by males ( $7 \%$, exclusively Berberis).

Dietary breadth showed no significant differences between sexes during the year. Considering plant categories, both sexes reached the highest breadth value in winter (males -0.29 , females -0.32 ) and the lowest in summer (males -0.06 , females - 0.04). Similar changes were shown by variation coefficients among individuals within each sex, the lowest values occurring in summer (males $-6.4 \%$, females $-3.7 \%$ ), and the highest in winter for females $(60 \%)$ and in spring for males $(41 \%)$.

Relative frequencies of each plant category for each age class were compared between males and females in summer and autumn; no significant differences were obtained. Then both sexes were grouped for dietary comparisons between immature and mature animales. No significant differences in the number of frequently used resources, food-niche breadth and relative frequency of different plant categories were found between both seasons.

\section{Discussion}

\section{Seasonal variations in the diet}

The high number of plant species eaten by $C$. mendocinus, about $65 \%$ of the genera present in the field, supports the dietary generalism previously observed for this species (Madoery 1993), and also for most subterranean mammals (Nevo 1979, Huntly and Reichman 1994). Williams and Cameron (1986), and Heth et al. (1989) ascribe this foraging strategy to the high energetic requirements imposed by the subterranean life style, derived from burrowing costs.

On the other hand, the high proportion of grasses in C. mendocinus diet, and its intensive and continued use throughout the year, evidence a specialization for this plant category, mainly constituted by perennial monocotyledons. Low shrubs, all of them perennial dicotyledons, follow grasses in dietary importance, but with a much lower proportion. A preference for grasses throughout the year has been recorded in C. mendocinus (Madoery 1993), as well as in C. australis and C. talarum (Comparatore et al. 1995). Moreover, captive individuals of $C$. mendocinus showed a selective use of Pappophorum and Panicum, against Cassia and Atriplex shrubs (Camín and Madoery 1994). 
Predation risk could be one of the determinant factors in the dietary selection of $C$. mendocinus, since it favours a minimization of the exposure time out of the burrow. Usual surface foraging was detected by Puig et al. (1992), Camín and Madoery (1994), and Rosi et al. (1996b). The use of monocotyledons could represent lower harvesting and handling times for this rodent than that of dicotyledons, as Randolph et al. (1991) have experimentally determined for Sigmodon hispidus. Also, harvesting grasses is easy from inside the tunnels; this behaviour has been mentioned for Geomys attwateri by Williams and Cameron (1986).

The grasses Poa, Panicum and Stipa, and the low shrubs Atriplex and Senecio stand out as major elements of Ctenomys diet according to the intensity and continuity of their use. The intensive use of Poa lanuginosa despite its scarce cover (1.5\%; Méndez 1992) suggests a selective search by C. mendocinus. Comparatore et al. (1995), who proved a high preference for Poa bonaerense in C. australis and C. talarum, attributed this preference to the high protein percentage and digestibility showed by several species of $P o a$ in reproductive status. The uniform distribution and high cover in the environment (Méndez 1992) could account for the high use of Panicum urvilleanum, a forage of intermediate quality (Wainstein and González 1971). The importance of Stipa spp. in the winter and spring diets of C. mendocinus does not reflect its scarce abundance (<1\%, Méndez 1992) nor its low foraging quality (Wainstein and González 1962). Nevertheless, Stipa is the main component of plant deposits recorded within burrow systems of C. mendocinus (Puig et al. 1992), and this could be a strategy to have grass available during the period of scarcity. Atriplex lampa, the most eaten shrub, had a low cover (5\%, Méndez 1992), but was nutritionally classified as a good forage in arid regions (Passera and Borsetto 1989).

The phenological cycle of perennial monocotyledons and dicotyledons in the Piedmont of Mendoza seems to explain seasonal changes in the proportion of plant categories within $C$. mendocinus diet. The vegetative period of grasses lasts from spring to late autumn (Passera et al. 1983, Dalmasso 1994), while for shrubs budding lasts from late winter to early spring (Braun et al. 1978). According to this seasonality of food resources, Ctenomys seems to compensate for the low nutritional quality of mature grasses in winter (Morrison 1969) with an increase in the use of shrubs and succulents, and the inclusion of 12 genera in the diet, among those the complete forbs category. The greatest among-individual variation was obtained in this period, coincidently with the trophic niche expansion. A more diverse food-niche at a population level produced by individual specialization on different food items has already been detected in other rodents (Kincaid and Cameron 1982, Luo et al. 1994). The lower values of dietary diversity and among-individuals variation obtained in summer suggest that all the individuals of the population concentrated their diet on a few preferred resources. This foraging behaviour agrees with one prediction of the optimal foraging theory: that an increase in food abundance or in its nutritional level will produce a higher dietary specialization (Pyke et al. 1977, Krebs 1978). 


\section{Diet according to sex and age class}

Different foraging strategies according to age and sex were recorded in several species of rodents (Clark 1980, Williams and Cameron 1986, Randolph et al. 1991), and were mainly attributed to differential nutritional requirements related with growing and reproduction. Dietary differences between sexes detected in C. mendocinus in winter and spring seem to reflect differences in the activity of each sex during the reproductive season. A similar behaviour was recorded in the fossorial rodent Thomomys bottae by Bandoli (1981).

A more varied winter diet in males could be explained by changes at the beginning of reproductive season, when the need to contact potential mates increases their burrowing activities. This fact determines longer and more linear burrow systems than those of females (Reichman et al. 1982, Rosi et al. 1996b), and the intersection of a higher number of food items, which makes their incorporation in the males diet easier.

In several rodent species, females showed dietary changes during pregnancy, lactating period or both simultaneously, associated with higher energetic and nutritional requirements (Randolph et al. 1977, 1991, Stebbins 1977, Andersen and MacMahon 1981, Batzli 1986, Oswald and McClure 1990). The higher number of frequently used species in the diet of females during spring seems to be related to an increase in their energetic and nutritional requirements in order to supply the reproductive costs. In fact, the females in the studied population have their first litter in mid-spring, and evidence of pregnancy from post-partum or mid-lactation oestrus, which produces the birth of a second litter (Rosi et al. 1996a). Females showed a higher specialization on grasses than males during this period, presumably because of the need to reduce searching for food, and consequently to select food items which are easier to harvest and handle, or to use plant deposits that already exist in their burrows. The decrease of burrowing activities during the partum and lactating period has also been mentioned for other burrowing species of rodents (Hansen 1960, Busch et al. 1989).

The dietary comparison between reproductive and non-reproductive mature females, as made for other rodents (Williams and Cameron 1986, Randolph et al. 1991), was hindered by a strong imbalance in the seasonal number of samples produced by the reproductive cycle in $C$. mendocinus. Most females were pregnant or lactating in winter and spring, while in summer immature and non-reproductive mature females (parous) predominated. It was also impossible to group the three samples corresponding to the reproductive period, as Williams and Cameron (1986) made for Geomys attwateri, due to significant differences in the dietary proportions of grasses and low shrubs.

Age does not seem to affect the feeding behaviour of $C$. mendocinus, according to dietary similarities among immature and mature individuals recorded in summer and autumn. Nevertheless, immature of 1-2 months old represent a low percentage in the immature group, and were captured only in summer and autumn (Rosi et al. 1996a). A probable low capture rate for this group could have hindered 
the detection of dietary differences at the beginning of the independent foraging period.

C. mendocinus dietary behaviour reflects seasonal variations in available resources. Sexual dimorphism in home range and body size (Rosi et al. 1996b) does not seem to affect foraging strategy. Different physiological requirements associated with reproduction could account for seasonal differences in feeding behaviour. C. mendocinus specialization in grasses and its seasonal variations in dietary diversity suggest a foraging strategy adaptive to environmental seasonal variations and to the subterranean life style.

Aknowledgements: We thank F. Videla for his invaluable support during collection and processing of the data, E. Méndez and M. Medero for their assistance on the botanical and biochemical aspects, respectively, and R. González del Solar for the English version. This study was supported by the CONICET through a research grant.

\section{References}

Andersen D. C. and MacMahon J. A. 1981. Population dynamics and bioenergetics of a fossorial herbivore, Thomomys talpoides (Rodentia: Geomyidae), in a spruce-fir sere. Ecological Monographs 51: $179-202$.

Bandoli J. H. 1981. Factors influencing seasonal burrowing activity in the pocket gopher, Thomomys bottae. Journal of Mammalogy 62: 293-303.

Batzli G. O, 1986. Nutritional ecology of the California vole: effects of food quality on reproduction. Ecology 67: 406-412.

Baumgartner L. L. and Martin A. C. 1939. Plant histology as an aid in squirrel food habit studies. The Journal of Wildlife Management 3: 266-268.

Braun R. H., Candia R. J., Leiva R., Paez M. N., Stasi C. R. and Wuilloud C. F. 1978. Productividad primaria aérea neta del algarrobal de Ñacuñán (Mendoza). Deserta 5: 7-43.

Busch C., Malizia A. I., Scaglia O. A. and Reig O. A. 1989. Spatial distribution and attributes of a population of Ctenomys talarum (Rodentia, Octodontidae). Journal of Mammalogy 70: 204-208.

Camín S. R. and Madoery L. A. 1994. Feeding behavior of the tuco tuco (Ctenomys mendocinus): its modifications according to food availability and the changes in the harvest pattern and consumption. Revista Chilena de Historia Natural 67: 257-263.

Capitanelli R. 1972. Geología, geomorfología, climatología, fitogeografía y zoogeografía de la provincia de Mendoza. Suplemento del Boletín de la Asociación Argentina de Botánica 13: 15-49.

Clark D. A. 1980. Age- and sex-dependent foraging strategies of a small mammalian omnivore. Animal Ecology 49: 549-563

Cockburn A. 1981. Population regulation and dispersion of the smoky mouse, Pseudomys fumeus. I. Dietary determinants of microhabitat preference. Australian Journal of Ecology 6: 231-254.

Comparatore V. M., Cid M. S. and Busch C. 1995. Dietary preferences of two sympatric subterranean rodent populations in Argentina. Revista Chilena de Historia Natural 68: 197-206.

Dalmasso A. D. 1994. Fenología de cinco gramíneas nativas de interés forrajero, Pappophorum caespitosum, Trichloris crinita, Setaria leucopila, Digitaria californica y Diplachne dubia. Multequina 3: 9-34.

Duci J. L. 1949. Methods for the determination of food habits by plant microtechniques and histology and their application to cotton tail rabbit food habits. The Journal of Wildlife Management 13: 295-298.

Gales R. P. 1982. Age- and sex-related difference in diet selection by Rattus on Steward Island, New Zealand. New Zealand Journal of Zoology 9: 463-466. 
Hansen R. M. 1960. Age and reproductive characteristics of mountain pocket gophers in Colorado. Journal of Mammalogy 41: 323-335.

Heth G., Golenberg E. M. and Nevo E. 1989. Foraging strategy in a subterranean rodent, Spalax ehrenbergi: a test case for optimal foraging theory. Oecologia 79: 496-505.

Holechek J. and Gross B. 1982. Evaluation of different calculation procedures for microhistological analysis. Journal of Range Management 35: 721-723.

Huntly N. and Reichman O. J. 1994. Effects of subterranean mammalian herbivores on vegetation. Journal of Mammalogy 75: 852-859.

Kincaid W. B. and Cameron G. N. 1982. Dietary variation in three sympatric rodents on the Texas coastal prairie. Journal of Mammalogy 63: 668-672.

Krebs C. J. 1989. Ecological Methodology. Collins, New York: 1-654.

Krebs J. R. 1978. Optimal foraging: Decision rules for predators. [In: Behavioral Ecology: An Evolutionary Approach. J. R. Krebs and N. B. Davies, eds]. Blackwell, Oxford: 23-63.

Luo J., Fox B. J. and Jefferys E. 1994. Diet of the Eastern Chestnut Mouse (Pseudomys gracilicaudatus). I. Composition, diversity and individual variation. Wildlife Research 21: 401-417.

Madoery L. 1993. Composición botánica de la dieta del tuco-tuco (Ctenomys mendocinus) en el piedemonte precordillerano. Ecología Austral 3: 49-55.

Méndez E. 1992. Conservación de nuestros ecosistemas naturales. I. Los médanos de Potrerillos (Luján de Cuyo, Mendoza). Multequina 1: 19-23.

Morrison F. B. 1969. Alimentos y alimentación del ganado. Uteha, México: 737-1346.

Nevo E. 1979. Adaptive convergence and divergence of subterranean mammals. Annual Review of Ecology and Systematics 10: 269-308.

Oswald Ch. and McClure P. A. 1990. Energetics of concurrent pregnancy and lactation in cotton rats and woodrats. Journal of Mammalogy 71: 500-509.

Passera C. B. Dalmasso A. D. and Duffar E. 1983. Ambiente físico y vegetación de las pampas de los Ñangos y Seca, Mendoza-Argentina. Deserta 7: 108-144.

Passera C. B. and Borsetto O. 1989. Aspectos ecológicos de Atriplex lampa. Investigaciones Agrarias: Producción y Protección vegetales 4: 179-198.

Puig S., Rosi M. I., Videla F. and Roig V. G. 1992. Estudio ecológico del roedor subterráneo Ctenomys mendocinus en la precordillera de Mendoza, Argentina: densidad poblacional y uso del espacio. Revista Chilena de Historia Natural 65: 247-254.

Pyke G. H., Pulliam H. R. and Charnov E. L. 1977. Optimal foraging: a selective review of theory and tests. The Quarterly Review of Biology 52: 137-154.

Randolph P. A., Randolph J. C., Mattingly K. and Foster M. M. 1977. Energy costs of reproduction in the cotton rat, Sigmodon hipidus. Ecology 58: 31-45.

Randolph J. C., Cameron G. N. and Wrazen J. A. 1991. Dietary choice of a generalist grassland herbivore, Sigmodon hispidus. Journal of Mammalogy 72: 300-313.

Reichman O. J., Whitham T. G. and Ruffner G. A. 1982. Adaptive geometry of burrow spacing in two pocket gopher populations. Ecology 63: 687-695.

Reig O. A., Busch C., Ortells M. O. and Contreras J. R. 1990. An overview of evolution, systematics, population biology, cytogenetics, molecular biology and speciation in Ctenomys. [In: Evolution of subterranean mammals at the organismal and molecular levels. E. Nevo and O. A. Reig, eds]. Alan R. Liss Inc., New York: 71-96.

Rosi M. I., Scolaro J. A. and Videla F. 1992a. Distribución y relaciones sistemáticas entre poblaciones del género Ctenomys (Rodentia, Ctenomyidae) de la provincia de Mendoza (Argentina). Miscel.lània Zoològica 16: 207-222.

Rosi M. I., Puig S., Videla F. Madoery L. and Roig V. G. 1992b. Estudio ecológico del roedor subterráneo Ctenomys mendocinus en la precordillera de Mendoza, Argentina: Ciclo reproductivo y estructura etaria. Revista Chilena de Historia Natural 65: 221-233. 
Rosi M. I., Puig S., Videla F., Cona M. I. and Roig V. G. 1996a. Ciclo reproductivo y estructura etaria de C. mendocinus (Rodentia, Ctenomyidae) del Piedemonte de Mendoza, Argentina. Ecología Austral 6: 87-93.

Rosi M. I., Cona M. I., Puig S., Videla F. and Roig V. G. 1996b. Size and structure of burrow systems of the fossorial rodent $C$. mendocinus in the piedmont of Mendoza province, Argentina. Zeitschrift für Säugetierkunde 61: 352-364.

Stebbins L. L. 1977. Energy requirements during reproduction of Peromyscus maniculatus. Canadian Journal of Zoology 55: 1701-1704.

Van Valen L. 1978. The statistics of variation. Evolutionary Theory 4: 33-43.

Vleck D. 1979. The energy cost of burrowing by the pocket gopher Thomomys bottae. Physiological Zoology 52: 122-136.

Wainstein P. and González S. 1962. Valor forrajero de trece especies de Stipa de Mendoza. Revista de la Facultad de Ciencias Agrarias (Mendoza) 9: 3-18.

Wainstein P. and González S. 1971. Valor nutritivo de plantas forrajeras del este de la provincia de Mendoza (Reserva Ecológica de Ñacuñán), II. Deserta (IADIZA) 2: 77-85.

Williams L. R. and Cameron G. N. 1986. Food habits and dietary preferences of Attwater's pocket gopher, Geomys attwateri. Journal of Mammalogy 67: 489-496.

Wilson D. E. and Reeder D. A. M. (eds) 1993. Mammal species of the world. A taxonomic and geographic reference. Smithsonian Institution Press, Washington and London: 1-1206.

Zar J. H. 1984. Biostatistical analysis. Second edition. Prentice-Hall Inc., New Jersey: 1-718.

Received 7 August 1997, accepted 2 November 1998. 